\title{
Phytochemical profiling and antioxidant activities of different parts of Artocarpus heterophyllus Lam. (Moraceae): A review on current status of knowledge
}

\author{
P. S. Sreeja Devi ${ }^{1}$, Neethu S. Kumar ${ }^{1}$ and K. K. Sabu ${ }^{2 *}$ (D)
}

\begin{abstract}
Background: Artocarpus heterophyllus Lam. (Jackfruit tree) is one of the most ancient fruits indigenous to Western Ghats of India. They are large edible summer fruits and are good source of nutritional and antioxidant components which hold their potential for nutraceutical development.

Main body: The present review attempts to document reports on the chemical and pharmacological investigations carried out with jackfruit. Research shows that the fruit contains a huge amount of phytochemicals such as phenolics, flavonoids, terpenoids, steroids, glycosides, saponins, alkaloids, and tannins which exhibit antioxidant properties.

Conclusions: Diversity of secondary metabolites present in the jackfruit shows that it is a functionally, nutritionally, and medicinally important fruit. Detailed studies are essential for awareness among people for the proper use of jackfruit as a functional food and utilize the medicinal uses of jackfruit.
\end{abstract}

Keywords: Jackfruit, Antioxidant property, Phenolics, DPPH

\section{Background}

Jackfruit is one among the most ancient fruits indigenous to Western Ghats of India. It is large edible summer fruit and is known to be the "Poor man's food" [1,2]. Locally, jackfruit is known to be "Chakka" while Sanskrit refers it to be Panasa (synonym: Atibruhatphala which means big fruit) [2-4]. Jackfruit is a good source of nutritional and antioxidant compounds which hold their potential for nutraceutical development. These phytonutrients promote opportunities for manufacturing value-added products $[5$, 6]. Research shows that compounds such as flavonoids and phenolics exhibit antioxidant properties $[7,8]$.

\footnotetext{
* Correspondence: sabu@jntbgri.res.in

Biotechnology and Bioinformatics Division, Jawaharlal Nehru Tropical Botanic Garden and Research Institute (JNTBGRI), Accredited Centre for research of University of Kerala, Palode, Thiruvananthapuram, Kerala 695562 , India

Full list of author information is available at the end of the article
}

\section{Main text}

Distribution

The jackfruit tree is widely distributed in tropical countries such as Brazil, Thailand, Indonesia, India, Philippines, and Malaysia [9]. Jackfruit is a common tree in every house of tropical and sub-tropical countries mainly Sri Lanka, Bangladesh, Burma, Philippines, Indonesia, Thailand, Malaysia, and Brazil $[4,10-16]$. In India, it is widely seen in several parts of the country [17].

\section{Morphology}

The fruit weighs up to $50 \mathrm{~kg}$ in which only $30-35 \%$ of the bulb is edible $[1,4,12,18-20]$. Jackfruit is a multiple (compound) fruit. It consists of a lower fleshy edible (bulb), middle fused (syncarp), and an outer spiny region (spike) [2]. When ripe, flakes get fleshy, outer spines widen, and flesh becomes soft and yellow in color [21]. The thorny outer bark and axis are not edible [4].
Springer Open
(0) The Author(s). 2021 Open Access This article is licensed under a Creative Commons Attribution 4.0 International License, which permits use, sharing, adaptation, distribution and reproduction in any medium or format, as long as you give appropriate credit to the original author(s) and the source, provide a link to the Creative Commons licence, and indicate if changes were made. The images or other third party material in this article are included in the article's Creative Commons licence, unless indicated otherwise in a credit line to the material. If material is not included in the article's Creative Commons licence and your intended use is not permitted by statutory regulation or exceeds the permitted use, you will need to obtain permission directly from the copyright holder. To view a copy of this licence, visit http://creativecommons.org/licenses/by/4.0/. 
Jackfruit is about 2- to 4-cm long consisting of about 100 to 500 seeds per fruit.

\section{Variety of jackfruit}

In jackfruit, the flake characteristics belong to two categories namely Varikka which consists of somewhat hard flakes and Koozha, consisting of soft and fibrous flakes [4, 22-25]. Further, jackfruits are classified based on their phenotypic and organoleptic characters with variation in their flakes and seed color, shape, size, odor, and period of maturity $[1-3,11]$.

\section{Phytochemical compositions}

The composition of jackfruit seeds has already been reported $[18,26]$ to possess similar compositions to that of grains. Phytochemical components in jackfruits may vary and depend upon the cultivar type as well as the habitat [3, 4, 27-29]. The fruit is rich in phytocompounds such as flavonoids, stillbenoids, morin, artocarpin, dihydromorin cynomacurin, isoartocarpin, cyloartocarpin, artocarpesin, artocarpetin, artocarpanone, oxydihydroartocarpesin, norartocarpetin, and cycloartinone [30], thus making it a potent antioxidant, anti-inflammatory, antibacterial, antifungal, anticariogenic, antineoplastic, cicatrizent, and hypoglycemic fruit.

\section{Nutritional aspects}

Jackfruit pulp is eaten afresh and is used in fruit salads and ice creams due to its high nutritional value [31]. The fat content of the seeds is negligible making it a good constituent of fat free diet. It is a source of vitamins and minerals $[3,20,27-29]$. The seeds may vary in their protein and carbohydrate contents, with certain varieties consisting of about $6.8 \%$ of proteins $[4,32,33]$, which is almost similar to that of rice, where it is about $7-8 \%$. The maximum sugar (21\%), carbohydrate (31\%), and protein $(2.3 \%)$ contents were reported to be in the flakes of Valayan, Mondan, and Nettadivarika varieties, respectively. Moreover, the seeds of these varieties were reported to have maximum carbohydrate $(42 \%)$ and protein $(6.8 \%)$ contents [33] (Table 1).

Major sugars, fatty acids, and carotenes are also present in jackfruit $[9,34-37]$. Jacalin is the major protein reported in the seed of jackfruit [37-40]. It is a lectin compound that can easily react with varieties of monosaccharides and can bind with human IgA [38, 41, 42] and T-antigen [43]. Besides, it has several health benefits such as anticancer, antioxidant, anti-ageing properties to mention a few $[3,20,44-46]$.

\section{Useful products}

The seeds are consumed either boiled or roasted and also used as a snack. However, fresh seeds have short shelf-life and so the seeds are dried or powdered to store for a long time. Jackfruit is widely used for preparing baby foods, jams, jellies, juice, biscuits, bread, chips, nectar, deserts, beverages like squash, wine, and so on $[3$, 18, 20, 28, 47, 48] (Table 2).

\section{Medicinal properties}

Jackfruit is both gluten-free and casein-free and hence has anti-inflammatory benefits to the skin. It has plenty of antioxidants, vitamin $\mathrm{C}$, various bioflavonoids, and fibers. It also has anti-cancerous property due to the presence of the protein jacalin and active bioflavonoids. Raw jackfruit is good to consume for diabetic patients, due to its antidiabetic property. Being fibrous and low in glycemic load (glucose level) jackfruit is widely accepted by the diabetologists as a perfect food source for diabetic patients. The glycemic index research conducted on jackfruit by the Sydney University had stated that one cup of jackfruit in which the glycemic value is 17 is almost half the glycemic value of other foods like chappathi (glycemic value-27) and rice (glycemic value-29).

\section{Phytochemical analysis}

Studies reveal that phytochemical screening tests have a significant role in the detection of bioactive principles and is mostly due to the presence of flavonoids, tannins, carbohydrates, saponins, alkaloids, tannins, triterpenoids, and proteins in the jackfruit peel extracts [49]. The phytochemical screening of aqueous, hydroalcoholic, and methanolic extracts of $A$. heterophyllus seeds indicate the presence of phytochemicals in the order of methanolic >hydroalcoholic >aqueous extracts which is an indication of its possible medicinal value [50]. The fruit peels

Table 1 Biochemical difference in different jackfruit varieties from Southern India [33]

\begin{tabular}{lllllll}
\hline SI. No. & $\begin{array}{l}\text { Name of } \\
\text { Variety }\end{array}$ & $\begin{array}{l}\text { Total soluble sugar } \\
\text { in flake (\%) }\end{array}$ & $\begin{array}{l}\text { Total carbohydrate } \\
\text { in flake (\%) }\end{array}$ & $\begin{array}{l}\text { Total protein } \\
\text { in flake (\%) }\end{array}$ & $\begin{array}{l}\text { Total carbohydrate } \\
\text { in seed (\%) }\end{array}$ & $\begin{array}{l}\text { Total protein } \\
\text { in seed (\%) }\end{array}$ \\
\hline 1 & Valayan & $21.3 \pm 1.02$ & $23.8 \pm 2.6$ & $1.4 \pm 2.2$ & $42.5 \pm 0.6$ & $5.9 \pm 0.7$ \\
2 & Nettadivarikka & $17.5 \pm 0.9$ & $28.4 \pm 1.7$ & $2.3 \pm 1.5$ & $40.3 \pm 2.3$ & $6.8 \pm 2.3$ \\
3 & Chemparathy & $20.7 \pm 0.4$ & $26.1 \pm 0.8$ & $1.9 \pm 2.7$ & $37.4 \pm 1.1$ & $5.3 \pm 1.4$ \\
4 & Mondan & $18.6 \pm 1.9$ & $31.2 \pm 2.0$ & $2.0 \pm 1.4$ & $42.8 \pm 0.9$ & $6.5 \pm 1.8$ \\
5 & Venkanni & $15.3 \pm 1.15$ & $28.4 \pm 1.3$ & $1.7 \pm 2.3$ & $40.2 \pm 1.5$ & $6.0 \pm 1.5$ \\
\hline
\end{tabular}

Numbers indicate means \pm standard deviation of mean 
Table 2 Uses of different jackfruit parts [20, 37]

\begin{tabular}{ll}
\hline Plant part & Use \\
\hline Fruit & $\begin{array}{l}\text { Food: Vegetable, pickle, chutney, jam, jelly, paste, } \\
\text { candies, juice, powder, confectionery }\end{array}$ \\
Seed & $\begin{array}{l}\text { Eaten boiled, roasted and salted as table nuts, flour for } \\
\text { baking, substrate for solid state fermentation, animal feed }\end{array}$ \\
Jackfruit peel & Adsorbent for the removal of cadmium \\
\hline
\end{tabular}

were extracted using 95\% ethanol in the soxhlet apparatus. The semi-solid extract so obtained was aromatic and pale brownish in color. The extractive value was found to be $15 \mathrm{~g}$ [51]. Quantitative phytochemicals estimated in seed powder in $100 \mathrm{~g}-1 \mathrm{DW}$ concerning tannins, saponins, and alkaloids were $1.45 \pm 0.29,2.67 \pm$ 0.17 , and $3.05 \pm 0.19$, respectively. Three different extracts aqueous acetone, aqueous methanol, and mix solvent were used to evaluate the phenolic and flavonoid contents and the quantitative analysis of polyphenols [52]. Dichloromethane:Methanol::1:1 solvent system was able to extract more phytochemicals in comparison to acetone in the seeds of jackfruit [53]. The highest extraction efficiency $(22.88 \%)$ was obtained in ethanolic leaf extract of A. heterophyllus [54]. High tannin content was estimated in the root $(3.88-2.69 \mathrm{mg} / \mathrm{g})$ and lowest in bark (0.93$0.52 \mathrm{mg} / \mathrm{g}$ ). Overall, the average tannin composition in all the parts reported so far is $2.14 \pm 0.45 \mathrm{mg} / \mathrm{g}$ [55].

\section{Total flavonoid content}

Total flavonoid content ( $\mu \mathrm{g} \mathrm{RE} / \mathrm{mg}$ extract) estimated from acetone extract of jackfruit seed was $290.6 \pm 3.41 \mu \mathrm{g} /$ $\mathrm{mg}$ and that from dichloromethane:methanol::1:1 extract was $457.1 \pm 5.82 \mu \mathrm{g} / \mathrm{mg}$ [56]. Flavonoid contents were assessed using aluminium chloride methods which revealed 96.7, 131.6, and $164.6 \mathrm{mg}$ quercetin equivalent/g of flavonoid in spine, skin, and rind, respectively [57]. In fresh tissues, the total flavonoid content was found out to be $10.1 \mathrm{QE} / \mathrm{g}$ of fresh tissue, respectively. Total flavonoid content was calculated for the standard curve of quercetin $\left(y=0.00148 x ; R^{2}=0.9988\right)$ and was estimated to be $10 \mathrm{mg}$ $\mathrm{QE} / \mathrm{g}$ dry weight [50]. When compared to standard (1.20 $\mathrm{mg}$ of RE/g), high-flavonoid content present in the edible part was estimated to be $10.5 \pm 0.21 \mathrm{mg} / 100 \mathrm{mg}$ [5]. The total flavonoid content of the four different extracts of $A$. heterophyllus was found to be $4.05 \pm 0.01 \mathrm{mg} / \mathrm{g}$ for ethanolic fraction, $2.21 \pm 0.02 \mathrm{mg} / \mathrm{g}$ for acetone fraction, 2.67 $\pm 0.01 \mathrm{mg} / \mathrm{g}$ for ethyl acetate fraction, and $0.86 \pm 0.01 \mathrm{mg} /$ $\mathrm{g}$ for an aqueous fraction of quercetin equivalent per 100 mg seed extract [58]. High-flavonoid content was also present in roots $(10.74-7.31 \mathrm{mg} / \mathrm{g})$ and lowest in bark $(3.09-1.49 \mathrm{mg} / \mathrm{g})$. Flavonoid contents $(\mathrm{mg} / \mathrm{g})$ obtained were $5.74,8.73$, and 2.24 for leaves, roots, and bark, respectively. Overall, the average flavonoid composition in all parts of the entire jackfruit was estimated to be 5.57 $\mathrm{mg} / \mathrm{g}$ [55] (Table 3).
Table 3 Phenolic, flavonoid content, and antioxidant activity of Jackfruit in undigested and digested extracts $[59,60]$

\begin{tabular}{lll}
\hline Parameters & Jackfruit undigested & Jackfruit digested \\
\hline Total phenolic content & $23.3 \pm 3.5$ & $33.9 \pm 0.8$ \\
Total flavonoid content & $33 \pm 9.5$ & $28.4 \pm 1.2$ \\
TEAC & $56 \pm 2.0$ & $218 \pm 12.0$ \\
ORAC & $2117 \pm 388$ & $3047 \pm 455$ \\
\hline
\end{tabular}

Numbers indicate means \pm standard deviation of mean

TEAC trolox equivalent antioxidant capacity, ORAC oxygen radical absorbance capacity

\section{Total phenolic compounds}

The highest total phenolic content was reported from $125 \mu \mathrm{g} / \mathrm{ml}$ of ethyl acetate fraction [61]. Total phenolic content ( $\mu \mathrm{g}$ gallic acid equivalents (GAE)/mg extract) determined from acetone extract of Jackfruit seed was estimated to be $1.45 \pm 0.007 \mu \mathrm{g} / \mathrm{mg}$ and $2.12 \pm 0.009 \mu \mathrm{g} /$ $\mathrm{mg}$ from dichloromethane:methanol (1:1) extract [56]. Polyphenol contents were assessed using Folin's Ciocalteu reagent which revealed 316, 355, and $382 \mathrm{mg}$ tannic acid equivalent/g of polyphenol in spine, skin, and rind, respectively [57]. Total phenolic content in fresh tissues obtained was $0.4 \mathrm{GAE} / \mathrm{g}$. Total phenolic content in the methanolic extracts of $A$. heterophyllus seeds was calculated using the standard curve of gallic acid $(y=$ $\left.1.4882 x-0.0067 ; R^{2}=0.950\right)$ was found to be $0.4 \mathrm{mg}$ GAE/g dry weight [50]. Phenolic content in the shell powder is higher than that reported earlier [5, 62]. Total phenolic contents obtained in four different solvents were $4.16 \pm 0.01 \mathrm{mg} / \mathrm{g}$ (ethanolic), $2.30 \pm 0.02 \mathrm{mg} / \mathrm{g}$ (acetone), $2.77 \pm 0.02 \mathrm{mg} / \mathrm{g}$ (ethyl acetate), and $1.18 \pm$ $0.01 \mathrm{mg} / \mathrm{g}$ (aqueous) of GAE at $100 \mathrm{mg} / \mathrm{g}$ of jackfruit seed extracts [58].The phenolic content of methanol extract of jackfruit seeds was $437 \pm 0.006 \mathrm{mg}$ of GAE/gm of the dried extract [63]. The highest phenolic content was observed in roots $(67.37-59.00 \mathrm{mg} / \mathrm{g})$ and lowest in barks $(38.14-28.34 \mathrm{mg} / \mathrm{g})$. Average phenolic contents $(\mathrm{mg} / \mathrm{g})$ reported were 35.18, 65.56, and 23.59 for the leaves, roots, and bark, respectively. Overall, the average phenolic composition of all the parts so far reported was $41.44 \mathrm{mg} / \mathrm{g}$ [55] (Table 3).

\section{Antioxidant activity}

Polyphenolic content and antioxidant properties in seed using dichloromethane:methanol::1:1 extract of jackfruit was found to be higher [56]. Maximum antioxidant activity has seen in leaf extract of methanol, water, ethanol, and ethyl acetate using ABTS, DPPH, and FRAP assays but not on petroleum ether extract [64]. Phenolic and flavonoid contents, antioxidant activity, and quantitative analysis of polyphenols were evaluated from three different extracts such as aqueous acetone, aqueous methanol, and mix of these solvents, of which the methanol the extract showed the highest antioxidant activity which is 
largely correlated with phenolic and flavonoid contents. The highest antioxidant activity is scavenging hydroxyl radical activity and followed by scavenging hydrogen peroxide and chelating of ferrous iron [65]. The antioxidant activity can be well preserved through storage at a lower temperature, perhaps due to the stability of protocatechuic acid (PCA). Findings indicate that jackfruit rind extract could be a potential source of antioxidants which could be utilized for developing value added products [66].

Total antioxidant capacity of the extracts was calculated by using percentage of inhibition against concentration of ascorbic acid $\left(y=0.1065 x+7.717 ; R^{2}=0.794\right)$. At $500 \mu \mathrm{g} / \mathrm{ml}$ concentration, methanolic extracts of seeds exhibited $31.06 \%$ inhibition. Studies on various parts of the jackfruit have shown the occurrence of higher antioxidant activity in seeds with IC50-410 $\mu \mathrm{g} / \mathrm{ml}$ [50]. The highest antioxidant activity shown is the scavenging hydroxyl radical activity followed by scavenging hydrogen peroxide and chelating of ferrous iron [65]. Total antioxidant capacity of jackfruit seeds was found to be $170.75 \pm 0.001 \mathrm{mg} /$ gm equivalent of ascorbic acid (Table 3).

\section{DPPH radical scavenging activity}

The dichloromethane:methanol::1:1 extract had shown higher radical scavenging activity $\left(\mathrm{IC}_{50}=0.6433 \pm\right.$ $0.0029 \mathrm{mg} / \mathrm{ml})$ than acetone extract $\left(\mathrm{IC}_{50}=0.7867 \pm\right.$ $0.0104 \mathrm{mg} / \mathrm{ml}$ ) by DPPH. Both the extracts were significantly different $(p<0.05)$ in their $\mathrm{IC}_{50}$ values [56] by DPPH assay. The values obtained by DPPH radical scavenging activity by the aqueous the extract was found to be more related to standard ascorbic acid than the ethanolic acid [67] (Table 4). The $\mathrm{IC}_{50}$ value for DPPH radical scavenging was found to be $398.8 \mu \mathrm{g} / \mathrm{ml}$ [50]. The antioxidant activity of the seed extracts in various solvents using DPPH assay had shown varying percentages of free radical scavenging activity. Methanol and ethyl acetate extracts showed $\mathrm{IC}_{50}$ values of $636.5 \mu \mathrm{g} / \mathrm{ml}$ and $715.86 \mu \mathrm{g} / \mathrm{ml}$, respectively [68]. There is a decrease in the absorbance of DPPH with the addition of jackfruit leaf and bark extract in DPPH solution. The greater the decrease in absorbance, the greater the antioxidant

Table 4 Results of DPPH assay showing \% inhibition with respect to ascorbic acid, ethanolic, and aqueous stem extracts of jackfruit [67]

\begin{tabular}{llll}
\hline Conc. $(\boldsymbol{\mu g} / \mathrm{ml})$ & Ascorbic acid & Ethanol extract & Aqueous extract \\
\hline 25 & $66.20 \pm 0.22$ & $61.25 \pm 0.29$ & $66.24 \pm 0.90$ \\
50 & $70.44 \pm 0.57$ & $62.54 \pm 0.62$ & $68.52 \pm 0.13$ \\
75 & $76.22 \pm 0.67$ & $64.22 \pm 0.56$ & $72.44 \pm 2.76$ \\
100 & $78.44 \pm 0.29$ & $67.77 \pm 0.56$ & $77.34 \pm 1.56$ \\
150 & $87.47 \pm 1.05$ & $74.24 \pm 2.33$ & $85.59 \pm 1.99$ \\
200 & $92.02 \pm 0.02$ & $76.23 \pm 0.24$ & $88.33 \pm 1.97$ \\
\hline
\end{tabular}

Numbers indicate means \pm standard deviation of mean activity. This positive result is indicated with the colour change of the solution from dark purple to bright yellow. The decrease in absorbance value occurs due to the electron transfer of the antioxidant hydrogen atom to $\mathrm{DPPH} . \mathrm{IC}_{50}$ of each extract can be calculated by plotting the concentration of the test solution and the percentage of inhibition of DPPH as a parameter of antioxidant activity. The $\mathrm{IC}_{50}$ for jackfruit leaf extract obtained was $52.08 \mathrm{mg} / \mathrm{ml}$, and for the bark extract, it was $33.93 \mathrm{mg} /$ $\mathrm{ml}$ [69]. In DPPH method, jackfruit seeds had shown moderate antioxidant potentiality in a dose-dependent manner with the $\mathrm{IC}_{50}$ value of $116.04 \mu \mathrm{g} / \mathrm{ml}$. The percentage scavenging of DPPH radical was found to be concentration-dependent with the $\mathrm{IC}_{50}$ value of $116.04 \mu \mathrm{g} / \mathrm{ml}$, while the $\mathrm{IC}_{50}$ value of standard ascorbic acid was found to be $9.02 \mu \mathrm{g} / \mathrm{ml}$. The DPPH scavenging activity was also highest in the roots (66-72\%), while that of the bark was (24-40\%) [66]. A study conducted in Egypt found that jackfruit leaf extracts at concentrations $0.2,0.4$, and $0.6 \mathrm{mg} / \mathrm{ml}$ scavenge by $70 \%$ ethanol to DPPH were 21,32 , and $51 \%$, respectively [59] (Table 4).

\section{ABTS scavenging activity}

Acetone extract $\left(\mathrm{IC}_{50}=0.0491 \pm 0.0005 \mathrm{mg} / \mathrm{ml}\right)$ and dichloromethane:methanol $(1: 1)\left(\mathrm{IC}_{50}=0.0556 \pm 0.0002\right.$ $\mathrm{mg} / \mathrm{ml}$ ) had shown less scavenging activity than that of standard ascorbic acid $\left(\mathrm{IC}_{50}=0.0027 \pm 0.0003 \mathrm{mg} / \mathrm{ml}\right)$ by ABTS scavenging assay [56]. Higher inhibition was measured by NSP35 water extract but in the case of petroleum ether extract, ABTS reagent was immiscible and hence antioxidant assay on petroleum ether leaf extract by using ABTS assay cannot be carried out [64]. A moderate correlation was found between total flavonoid and ABTS assays $(r=0.62)$ [52].

\section{Reducing power assay}

The results had shown that the reducing power of jackfruit seed extracts ranged from $13.12-9.56 \mu \mathrm{g} / \mathrm{ml}$ for various solvent extracts [58]. The reducing power of the roots, leaves, and bark ranged from 114.38 to $93.62 \mu \mathrm{g} / \mathrm{ml}, 71.63$ to $67.04 \mu \mathrm{g} / \mathrm{ml}$, and 54.16 to $33.15 \mu \mathrm{g} / \mathrm{ml}$, respectively [55]. Reducing power of dichloromethane:methanol::1:1 extract was found to be $16.678 \mu \mathrm{g} \mathrm{GAE} / \mathrm{mg}$, which was higher than that of acetone $(14.029 \mu \mathrm{g} \mathrm{GAE} / \mathrm{mg})$ extract [56]. FRAP was reported as $5 \mathrm{mg} / \mathrm{ml}$ for pulp methanolic extract [5]. The percentages of $\mathrm{Fe}^{++}$chelating activity of $70 \%$ ethanol were 62,75 , and $78 \%$ at concentrations of $0.2,0.4$, and $0.6 \mathrm{mg} / \mathrm{ml}$, respectively [70].

\section{Hydrogen peroxide scavenging activity}

It was observed that the chloroform and hexane extracts showed scavenging activity above $50 \%$. The $\mathrm{EC}_{50}$ (free radical scavenger) values of ethanolic, hexane, chloroform, and ethyl acetate extracts were $76.71,399.64,534.83$, and $65.51 \mu \mathrm{g} / \mathrm{ml}$, 
respectively [61]. Other studies using ethanolic and methanolic extracts of the jackfruit seeds showed comparable values with that of the ascorbic acid standard $[50,67]$.

\section{Lipid peroxidase, superoxide radical rcavenging, and nitric oxide scavenging assays}

Removal of $\mathrm{H}_{2} \mathrm{O}_{2}$ is essential for maintaining redox balance within a cell. It was found that scavenging of $\mathrm{H}_{2} \mathrm{O}_{2}$, and its percentage inhibition in methanolic extracts of jackfruit seeds exhibited an $\mathrm{IC}_{50}$ value of $32.51 \mu \mathrm{g} / \mathrm{ml}$ while that of the ascorbic acid standard was found to be $31.99 \mu \mathrm{g} / \mathrm{ml}$ [50]. Lipid peroxidase, superoxide radical scavenging, and nitric oxide scavenging assays showed that there have been significant inhibitions of free radicals with ethanolic and aqueous extracts of jackfruit seeds as compared with the standard ascorbic acid [67].

\section{Future directions}

Jackfruit is declared as the State fruit of Kerala state by the Government of India in March 2018. Jackfruit tree is ecofriendly and produces pesticide-free fruit as the tree has no serious pests and diseases. Usually, jackfruit tree produces plenty of fruits during the fruiting season and people use jackfruit in different forms even though many fruits and seeds are wasted on large scale due to its high availability during every season. Hence, it becomes essential to create awareness among people for the functional and medicinal uses of jackfruit besides converting fruits and seeds to value-added products. Further, awareness creation is essential for indiscriminate cutting of the trees in large numbers for timber which in turn will reduce its genetic diversity remaining in the species. There is no scientific study carried out so far on the local jackfruit varieties in Kerala. It is very important to conserve the locally available jack trees for the maintenance of biodiversity and future use. Management system should take appropriate action for its proper conservation and utilization of these important genetic resources. In ancient times, people in Kerala used jackfruit when food was scarce and used as a common food item like rice. But today, unfortunately, nobody is aware of the priceless medicinal as well as nutritional properties which this fruit has to offer when it is included in our daily diet. Further studies would help to promote the consumption of jackfruit regularly by the general public and offers the opportunity to develop value-added products.

\section{Conclusion}

The present review reveals that Artocarpus heterophyllus Lam. is a chemically and pharmacologically studied tree having diverse secondary metabolites present in its fruits and seeds such as phenolics, flavonoids, terpenoids, steroids, glycosides, saponins, alkaloids, and tannins. Thus, jackfruit is considered to be a functionally, nutritionally, and medicinally important fruit in all respects.

\section{Abbreviations}

DPPH: 2,2-Diphenyl-1-picryl hydrazyl; QE/g: Quercetin equivalent per gram; RE/g: Rutin equivalent per gram; GAE: Gallic acid equivalents; ABTS: 2,2'Azino-Bis(3-ethyl benzothiazoline-6-sulfonic acid); FRAP: Fluorescence recovery after photobleaching; TE: Trolox equivalents; $\mathrm{IC}_{50}$ : Half maximal inhibitory concentration; JFBE: Jackfruit n-butanol extract; $\mathrm{EC}_{50}$ : Half maximal effective concentration

\section{Acknowledgements}

We sincerely thank to the Principal of Mahatma Gandhi College and to the Director of Jawaharlal Nehru Tropical Botanic Garden and Research Institute, Thiruvananthapuram, Kerala, India, for the facilities.

\section{Authors' contributions}

PSSD collected the data and drafted the manuscript. NSK and KKS analysed the collected literature and finalized the manuscript. The authors read and approved the final manuscript.

\section{Funding}

This work was supported by the University of Kerala by providing Junior Research Fellowship to PSSD.

Availability of data and materials

All data and material are available upon request.

Ethics approval and consent to participate

Not applicable.

\section{Consent for publication}

Not applicable.

\section{Competing interests}

The authors declare no conflict of interest.

\section{Author details}

${ }^{1}$ Post Graduate Department and Research Centre of Botany, Mahatma Gandhi College, Accredited Centre for Research of University of Kerala, Kesavadasapuram, Thiruvananthapuram, Kerala 695004, India. ${ }^{2}$ Biotechnology and Bioinformatics Division, Jawaharlal Nehru Tropical Botanic Garden and Research Institute (JNTBGRI), Accredited Centre for research of University of Kerala, Palode, Thiruvananthapuram, Kerala 695562, India.

Received: 31 May 2020 Accepted: 7 January 2021

Published online: 28 January 2021

References

1. Jagadeesh SL, Reddy BS, Basavaraj N, Swamy GSK, Gorbal K, Hegde L, Raghavan GSV, Kajjidoni ST (2007) Inter tree variability for fruit quality in jackfruit selections of Western Ghats of India. Sci Hortic 112(4):382-387

2. Prakash O, Kumar R, Mishra A, Gupta R (2009) Artocarpus heterophyllus (Jackfruit): an overview. Pharmacogn Rev 3:353-358

3. Haq N (2006) Jackfruit (Artocarpus heterophyllus). In: Williams JT, Smith RW, Dunsiger Z (eds) Tropical fruit trees. Southampton Centre for Underutilised Crops, University of Southampton., Southampton

4. Baliga MS, Shivashankara AR, Haniadka R, Dsouza J, Bhat HP (2011) Phytochemistry, nutritional and pharmacological properties of Artocarpus heterophyllus Lam (jackfruit): a review. Food Res Int 44(7):1800-1811

5. Umesh JB, Panaskar Shrimant N, Bapat VA (2010) Evaluation of antioxidant capacity and phenol content in jackfruit (Artocarpus heterophyllus Lam.) fruit pulp. Plant Foods Hum Nutr 65(2):99-104

6. Jagtap UB, Bapat VA (2013) Green synthesis of silver nanoparticles using Artocarpus heterophyllus Lam. seed extract and its antibacterial activity. Ind Crops Prod 46(1):132-137

7. Rice-Evans CA, Miller NJ, Paganga G (1996) Structure-antioxidant activity relationships of flavonoids and phenolic acids. Free Radic Biol Med 20:933-956

8. Wang SY, Lin HS (2000) Antioxidant activity in fruits and leaves of blackberry, raspberry, and strawberry varies with cultivar and developmental stage. J Agric Food Chem 48:140-146

9. Chawdhary FA, Raman MA (1997) Distribution of free sugars and fatty acids in jackfruit. Food Chem 60(1):25-28 
10. Maia JGS, Andrade EHA, Zoghbi MDGB (2004) Aroma volatiles from two fruit varieties of jackfruit (Artocarpus heterophyllus Lam.). Food Chem 85(2): 195-197

11. Jagadeesh SL, Reddy BS, Swamy GSK, Gorbal K, Hegde L, Raghavan GSV (2007) Chemical composition of jackfruit (Artocarpus heterophyllus Lam.) selections of Western Ghats of India. Food Chem 102(1):361-365

12. Hameed BH (2009) Removal of cationic dye from aqueous solution using jackfruit peel as non-conventional low-cost adsorbent. J Hazard Mater 162(1):344-350

13. Lin KW, Liu CH, Tu HY, Ko HH, Wei BL (2009) Antioxidant prenylflavonoids from Artocarpus communis and Artocarpus elasticus. Food Chem 115(2):558-562

14. Saxena A, Bawa AS, Raju PS (2009) Optimization of a multitarget preservation technique for jackfruit (Artocarpus heterophyllus L.) bulbs. J Food Eng 91(1):18-28

15. Dutta H, Paul SK, Kalita D, Mahanta CL (2011) Effect of acid concentration and treatment time on acid-alcohol modified jackfruit seed starch properties. Food Chem 128(2):284-291

16. Siti Balqis Z, Rosma A (2011) Artocarpus integer leaf protease: purification and characterisation. Food Chem 129(4):1523-1529

17. Wangchu L, Singh D, Mitra SK (2013) Studies on the diversity and selection of superior types in jackfruit (Artocarpus heterophyllus Lam.). Genet Resour Crop Evol 60(5):1749-1762

18. Selvaraj Y, Pal DK (1989) Biochemical changes during ripening of jackfruit (Artocarpus heterophyllus L). J Food Sci Technol 26:304-307

19. Saxena A, Bawa AS, Raju PS (2009) Phytochemical changes in fresh-cut jackfruit (Artocarpus heterophyllus L.) bulbs during modified atmosphere storage. Food Chem 115(4):1443-1449

20. Swami SB, Thakor NJ, Haldankar PM, Kalse SB (2012) Jackfruit and its many functional components as related to human health: a review. Compr Rev Food Sci Food Saf 11(6):565-576

21. Saxena A, Bawa AS, Raju PS (2009) Optimization of a multi target preservation technique for jackfruit (Artocarpus heterophyllus L.) bulbs. J Food Eng 91(1):18-28

22. Muralidharan VK, Ganapathy MM, Velayudhan KC, Amalraj VA (1997) Collecting jackfruit germplasm in Western Ghats. Indian J Plant Genet Resour 10(2):227-231

23. Odoemelam SA (2005) Functional properties of raw and heat processed jackfruit (Artocarpus heterophyllus) flour. Pak J Nutr 4(6):366-370

24. Shyamalamma S, Chandra SBC, Hegde M, Naryanswamy P (2008) Evaluation of genetic diversity in jackfruit (Artocarpus heterophyllus Lam.) based on amplified fragment length polymorphism markers. Genet Mol Res 7(3):645-656

25. Amma SP, Kumaran K, Valavi SG, Peter KV, Thottappilly G (2011) Jackfruit in South India. The jackfruit. Studium Press LLC, Houston

26. Rahman AKMN, Huq E, Mian AJ, Chesson A (1995) Microscopic and chemical changes occurring during the ripening of two forms jackfruit (Artocarpus heterophyllus L.). Food Chem 52:405-410

27. Arkroyd WR, Gopalan C, Balasubramanuyam SC (1966) The nutritive value of Indian food and the planning of satisfaction diet. Sept. Rep. Ser., vol 42. Indian Council of Medical Research, New Delhi

28. Narasimham P (1990) Breadfruit and jackfruit. In: Nagy S, Shaw PE, Wardowski WF (eds) Fruits of tropical and subtropical origin: composition, properties and uses. Florida Science Source Inc, Florida, pp 193-259

29. Azad AK (2000) Genetic diversity of jackfruit in Bangladesh and development of propagation methods. Ph.D. thesis, University of Southampton, UK

30. Wetprasit N, Threesangsri W, Klamklai N, Chulavantol M (2000) Jackfruit lectin: properties of mitogenicity and the inhibition of herpes virus infection. Jpn J Infect Dis 53:156-161

31. Samaddar HM (1985) Jackfruit. In: Bose TK, Mishra SK (eds) Fruits of India: tropical and subtropical. Naya Prokash, Calcutta, pp 638-649

32. Chaudhari PR, Tamrakar N, Singh L, Tandon A, Sharma D (2018) Rice nutritional and medicinal properties: A. J Pharmacogn Phytochem 7(2):150-156

33. Chrips NR, Balasingh GR, Kingston C (2008) Nutrient constituents of neglected varieties of Artocarpus heterophyllus Lam. from Kanyakumari district, South India. J Basic Appl Biol 2(3\&4):36-37

34. Chowdhury S, Ahmed H, Chatterjee BP (1991) Chemical modification studies of Artocarpus lakoocha lectin artocarpin. Biochimie 73(5):563-571

35. Rahman MA, Nahar N, Mian AJ, Mosihuzzaman M (1999) Variation of carbohydrate composition of two forms of fruit from jack tree (Artocarpus heterophyllus L.) with maturity and climatic conditions. Food Chem 65(1):91-97
36. Ong BT, Nazimah SAH, Osman A, Quek SY, Voon YY, Hashim D, Chew PM, Kong YW (2006) Chemical and flavour changes in jackfruit (Artocarpus heterophyllus Lam.) Cultivar J3 during ripening. Postharvest Biol Technol 40(3):279-286

37. Jagtap UB, Panaskar SN, Bapat VA (2010) Evaluation of antioxidant capacity and phenol content in jackfruit (Artocarpus heterophyllus) fruit pulp. Plant Foods Hum Nutr 65:99-104

38. Chatterjee B, Vaith P, Chatterjee S, Karduck D, Uhlenbruck G (1979) Comparative studies of new marker lectins for alkali-labile and alkali-stable carbohydrate chains in glycoproteins. Int J Biochem 10(4):321-327

39. Young NM, Johnston RA, Watson DC (1991) The amino acid sequences of jacalin and the Maclura pomifera agglutinin. FEBS Lett 282(2):382-384

40. Kabir S, Aebersold R, Daar AS (1993) Identification of a novel 4 kDa immunoglobulin-A-binding peptide obtained by the limited proteolysis of jacalin. Biochim Biophys Acta 1161(2):194-200

41. Pereira ME, Loures MA, Villalta F, Andrade AF (1980) Lectin receptors as markers for Trypanosoma cruzi. Developmental stages and a study of the interaction of wheat germ agglutinin with sialic acid residues on epimastigote cells. J Exp Med 152(5):1375-1392

42. Saxon A, Tsui F, Martinez-Maza O (1987) Jacalin, an lgA-binding lectin, inhibits differentiation of human B cells by both a direct effect and by activating T-suppressor cells. Cell Immunol 104(1):134-141

43. Sastry MV, Banarjee P, Patanjali SR, Swamy MJ, Swarnalatha GV, Surolia A (1986) Analysis of saccharide binding to Artocarpus integrifolia lectin reveals specific recognition of T-antigen (a-D-Gal(1-3)D-GalNAc). J Biol Chem 261(1):11726-11733

44. Ko FN, Cheng ZJ, Lin CN, Teng CM (1998) Scavenger and antioxidant properties of prenylflavones isolated from Artocarpus heterophyllus. Free Radic Biol Med 25:160-168

45. Loizzo MR, Tundis R, Chandrika UG, Abeysekera AM, Menichini F, Frega NG (2010) Antioxidant and antibacterial activities on food borne pathogens of Artocarpus heterophyllus Lam. (Moraceae) leaves extracts. J Food Sci 75(5): M291-M295

46. Siritapetawee J, Thammasirirak S, Samosornsuk W (2012) Antimicrobial activity of a 48-kDa protease (AMP48) from Artocarpus heterophyllus latex. Eur Rev Med Pharmacol Sci 16(1):132-137

47. Roy SK, Joshi GD (1995) Minor fruits-tropical. In: Salunkhe DK (ed) Handbook of fruit science and technology. Marcel Dekker, Inc., New York

48. Burkill HM (1997) The useful plants of west tropical Africa, 2nd edn. Royal Botanic Gardens, Kew

49. Sundarraj AA, Ranganathan TV (2017) Phytochemical screening and spectroscopy analysis of jackfruit (Artocarpus integer Thumb.) peel. Int Res J Pharm 8(9):151-159

50. Bhat V, Mutha A, Dsouza MR (2017) Pharmacognostic and physiochemical studies of Artocarpus heterophyllus seeds. Int J ChemTech Res 10(9):525-536

51. Sundarraj AA, Ranganathan TV (2018) Phytochemical constituents and thinlayer chromatography evaluation of the ethanolic extract of jackfruit (Artocarpus integer) peel. J Pharm Res 12(5):717

52. Sharma A, Gupta P, Verma AK (2015) Preliminary nutritional and biological potential of Artocarpus heterophyllus L. shell powder. J Food Sci Technol 52(3):1339-1349

53. Nguyen $H$, Nguyen $H$, Le Nguyen CT (2015) Phytochemical, nutritional, laxative and hypoglycemic activity evaluation of seeds of Jackfruit (Artocarpus heterophyllus Lam). J Bot Sci 5(4):47-51

54. Sivagnanasundaram P, Karunanayake KOLC (2015) Phytochemical screening and antimicrobial activity of Artocarpus heterophyllus and Artocarpus altilis leaf and stem bark extracts. OUSL J 9:1-17. https://doi.org/10.4038/ouslj.v9i0.7324

55. Ojwang AR, Muge EK, Mbatia B, Mwanza B, Ogoyi D (2017) Comparative analysis of phytochemical composition and antioxidant activities of methanolic extracts of leaves, roots and bark of jackfruit (Artocapus heterophyllus) from selected regions in Kenya and Uganda. J Adv Biol Biotechnol 16(1):1-13. https://doi.org/10.9734/JABB/2017/37355

56. Gupta D, Mann S, Sood A, Gupta RK (2011) Phytochemical, nutritional and antioxidant activity evaluation of seeds of jackfruit (Artocarpus heterophyllus Lam.). Int J Pharma Bio Sci 2(4):336-345

57. Meera M, Ruckmani A, Saravanan R, Lakshmipathy Prabhu R (2018) Antiinflammatory effect of ethanolic extract of spine, skin and rind of jack fruit peel-a comparative study. Nat Prod Res 32(22):2740-2744

58. Shanmugapriya K, Saravana PS, Payal H, Mohammed SP, Binnie W (2011) Antioxidant activity, total phenolic and flavonoid contents of Artocarpus heterophyllus and Manilkara zapota seeds and its reduction potential. Int J Pharm Pharm Sci 3(5):256-260 
59. Pavan V, Sancho RAS, Pastore GM (2014) The effect of in vitro digestion on the antioxidant activity of fruit extracts (Carica papaya, Artocarpus heterophyllus and Annona marcgravii). LWT Food Sci Technol 59(2):1247-1251

60. Vazhacharickal PJ, Sajeshkumar NK, Mathew JJ, Kuriakose AC, Abraham B, Mathew RJ, Jose S (2015) Chemistry and medicinal properties of jackfruit (Artocarpus heterophyllus): a review on current status of knowledge. Int J Innov Res Rev 3(2):83-95

61. Burci LM, da Silva CB, de Oliveira M, Dalarmi L, Zanin SMW, Miguel OG, Miguel MD (2015) Determination of antioxidant, radical scavenging activity and total phenolic compounds of Artocarpus heterophyllus (Jackfruit) seeds extracts. J Med Plants Res 9(40):1013-1020

62. Soong YY, Philip Barlow J (2004) Antioxidant activity and phenolic content of selected fruit seeds. J Agric Food Sci Chem 88:411-417

63. Shirajum M (2014) Antioxidant and antidiarrhoeal activities of methanolic extract of Artocarpus heterophyllus seed. Int J Pharm Drug Anal 2(10):890-895

64. Prasad MP, Prasad K, Ceera M (2014) Phytochemical, antioxidant activity and determination of genetic diversity in Artocarpus heterophyllus using RAPD molecular markers. Int J Sci Res 3(10):44-49

65. Biworo A, Tanjung E, Iskandar K, Suhartono E (2015) Antidiabetic and antioxidant activity of jackfruit (Artocarpus heterophyllus) extract. J Med Bioeng 4(4):318-323

66. Daud MNH, Ahmad R, Abdullah N, Jabit ML, Wibowo A (2019) Effect of storage on antioxidant activity and bioactive compound of Artocarpus heterophyllus J33 rind extract. Adv Appl Chem Biochem 1:68-81

67. Ubaid K (2017) Antihyperlipidaemic and antioxidant activity of Artocarpus heterophyllus stem extract. Doctoral dissertation, Karpagam College of Pharmacy, Coimbatore

68. Sreeletha AS, Lini JJ, Dhanyalekshmi CS, Sabu KR, Pratap CR (2017) Phytochemical, proximate, antimicrobial, antioxidant and FTIR analyses of seeds of Artocarpus heterophyllus Lam. Adv Biotechnol Microbiol 5(1):555-653

69. Siregar AB, Bulan R, Yusak Y (2018) Antibacterial \& antioxidant properties of leave \& stem bark extract of Artocarpus heterophyllus as the component of peel-off mask. Int J Sci Technol Eng 5(4):101-106

70. Omar HS, El-Beshbishy HA, Moussa Z, Taha KF, Singab ANB (2011) Antioxidant activity of Artocarpus heterophyllus Lam. (Jackfruit) leaf extracts: remarkable attenuations of hyperglycemia and hyperlipidemia in streptozotocin-diabetic rats. Sci World J 11:788-800

\section{Publisher's Note}

Springer Nature remains neutral with regard to jurisdictional claims in published maps and institutional affiliations.

\section{Submit your manuscript to a SpringerOpen ${ }^{\circ}$ journal and benefit from:}

- Convenient online submission

- Rigorous peer review

- Open access: articles freely available online

- High visibility within the field

- Retaining the copyright to your article

Submit your next manuscript at $\boldsymbol{\nabla}$ springeropen.com 